\title{
Employment structure transformation through economic activity types perspective
}

\author{
Alexandr Almosov ${ }^{1}$, Yulia Brekhova ${ }^{2}$,Elena Malysheva ${ }^{3}$, Viktor Molokanov $^{4}$, and Ekaterina Chumakova $^{5 *}$ \\ ${ }^{1}$ Volgograd Institute of management - branch of The Russian Presidential Academy of National Economy and Public Administration, 8 \\ Gagarin street, Volgograd, Russia, almosov-ap@,vlgr.ranepa.ru \\ ${ }^{2}$ Volgograd Institute of management - branch of The Russian Presidential Academy of National Economy and Public Administration, 8 \\ Gagarin street, Volgograd, Russia, brekhova-yv@ranepa.ru \\ ${ }^{3}$ Dean of the faculty of Economics Volgograd Institute of management - branch of The Russian Presidential Academy of National \\ Economy and Public Administration, 8 Gagarin street, Volgograd, Russia, decanatec@vlgr.ranepa.ru \\ ${ }^{4}$ Associate Professor at the Department of Economics and Finance Volgograd Institute of management - branch of The Russian \\ Presidential Academy of National Economy and Public Administration, 8 Gagarin street, Volgograd, Russia, vikmol@inbox.ru \\ ${ }^{5}$ Associate Professor at the Department of Economics and Finance Volgograd Institute of management - branch of The Russian \\ Presidential Academy of National Economy and Public Administration, 8 Gagarin street, Volgograd, Russia, chumakova- \\ ea@vlgr.ranepa.ru
}

\begin{abstract}
The present study was conducted to identify the reasons in modern information society that caused significant changes in the labor market particularly in its industrial structure through the perspective of individuals employed in real and service sectors. The analysis of the employed population's statistical sample by economic activity type in enlarged groups of industrial and non-industrial spheres of activity over the past 20 years has shown that scientific and technological transformations have led to a significant shift in the employment structure. The research used statistical data comparison of economic activity types and the ratio of the regions employed in real and service sectors. New types of economic activity are emerging and start prevailing inherent exclusively in the current state of economy in the context of digitalization. A significant structural shift has been revealed in the course of the analysis of the employed population by the enlarged industry affiliation, which demonstrates diametrically opposite positions in the overall structure of employment. The resulting ratio allows us to propose and apply the coefficient of the employment structure, demonstrating a multiplier effect on identifying such jobs creation and preservation of which leads to further employment provisioning. The obtained tool allows managing population employment as well as related social and economic processes as migration outflow and population growth in all age groups, population reproduction, expansion and improvement of educational and health services in a particular territory. In addition, application of the developed employment structure tool allows estimating the amount of investment required to solve these issues.
\end{abstract}

\section{Introduction}

Labor market issues cannot leave on an arm's length neither federal nor regional or municipal authorities and citizen, since the changes at this "testing ground" are so tangible that they affect all components of the market from the amount of individual citizens' wages to macroeconomic employment indicators across both region and country [1].

It has become very interesting recently to study the labor market situation through economic transformation perspective as it was not yet the case several decades ago. In addition, the study of the labor market through the population employment perspective is always relevant since it is one of its main components in the workforce.
The study of the Russian Federation recent past reveals a radical change in approaches to the study of employment, its interpretations, legislative consolidation, and structure in various dimensions [2]. The authors believe that it makes sense to change the existing research vectors for new ones that take into account many factors of shifting reality. In the course of transition from total and universal employment typical for the Soviet economy to currently used employment assessment with unemployment as its constant component.

Therefore, nowadays in the context of significant changes in society with information priorities and dominants through the digitalization of the economy perspective, the scientific community cannot ignore employment and unemployment phenomena that

\footnotetext{
* Corresponding author: chumakova-ea@vlgr.ranepa.ru
} 
influence the very basic characteristics positioning in labor market [3], [4].

\section{Problem Statement}

The interest of researchers and economists in employment study through various perspectives and contexts is obvious today. A number of current studies illustrate the following aspects:

- correlation between social and labor relations development and labor and entrepreneurship transformations with a focus on displacing a large number of the working-age population due to economy modernization [5], [6], [7];

- numerous barriers to the labor market from a regulatory and legal point of view and the corresponding instruments for its regulation [8], [9];

- statistical data on changes in the sex-age structure of the labor market [10], [11].

Assessment of population employment and its structure by industry, the scientific community only states statistics in dynamics, indicating its significant change, but in this direction the structural changes in employment by type of economic activity by segments of the production and non-production sectors of the economy as a result of its transformation which is undoubtedly an urgent area within the framework of solving a wide range of tasks related to labor market issues.

\section{Research Questions}

The study was aimed at getting answers to the following questions:

1. What structural changes in labor market have occurred from the transformation of the economy over the past decades?

2. What allows to assess the current ratio of the employed by type of economic activity?

3. What additional group of employed people can be identified in the service sector where jobs are financed by the government?

\section{Purpose of the Study}

The scientific inquiry made it possible to determine the goal of the study which centers on the development of the coefficient of the structure of population employment which makes it possible to assess how many jobs in the real sector of economy lead to the creation of work places in the service sector, as well as to assess the multiplier effects on the labor market of a particular territory using the example of the Volgograd region. In order to accomplish this goal the following tasks were set: to analyze employed population change of the Volgograd region by enlarged groups of types of economic activity; to propose an indicator describing the structure of population employment; to distinguish between the proposed coefficient of population structure of employment in certain types of economic activity, the creation of jobs in which is created by the state; to offer a lever of employment management in the labor market of a separate territory.

\section{Research Methods}

In the framework of this study, classical general scientific research methods were applied: economic and statistical methods of collecting and processing information, comparison, analogy, analysis, synthesis, induction and deduction, and graphic method.

\section{Findings}

In this paper, the analysis of employment of the population is carried out at the level of the Russian Federation as a whole and at the regional level in particular (using the example of the Volgograd region) through the perspective of the impact of economic modernization on the structure of employment, namely on significant changes in the structure of employment by industry for enlarged economic activity types.

Such changes are illustrated by the graphic cross which indicates that the last few decades the shares of individuals employed in the real sector of the economy and those employed in the service sector in the overall structure of employment of the population have taken diametrically opposite positions.

For the analyzed period of time a variety of completely new types of services and, as a result, new types of economic activity appeared. The production modernization has led to the release of able-bodied citizens from their jobs while the growth rates of labor productivity for different types of activities in the manufacturing sector of the economy are very different, but the obvious leader here is the agriculture sector where labor productivity has increased 20 times [12]. In these conditions, the transformation of the labor market and the structure of employment by industry seem logical.

Within the framework of this study, the assessment of the structure of employment of the population was carried out for enlarged subgroups of types of economic activity in accordance with the all-Russian classifier of types of economic activities of the Russian Federation the real sector of the economy (from "Agriculture" to "Construction") and the service sector (from "Wholesale trade" and retail to "Activities in the field of culture and sports").

This approach is justified since the study of the structural components of the employed labor force according to the enlarged groups of economic activity in the Russian Federation as a whole from 1990 to 2019, and in the Volgograd Region from 1995 to 2019 in the graphical representation has a diametrically opposite relationship with building up the existing trend.

Let us denote those employed in the real sector of the economy by A, and those employed in the service sector by $\mathrm{B}$ and demonstrate the dynamics of employment of 
the population in the manufacturing and nonmanufacturing sectors in the Russian Federation as a whole and in the Volgograd region (Figures 1, 2).

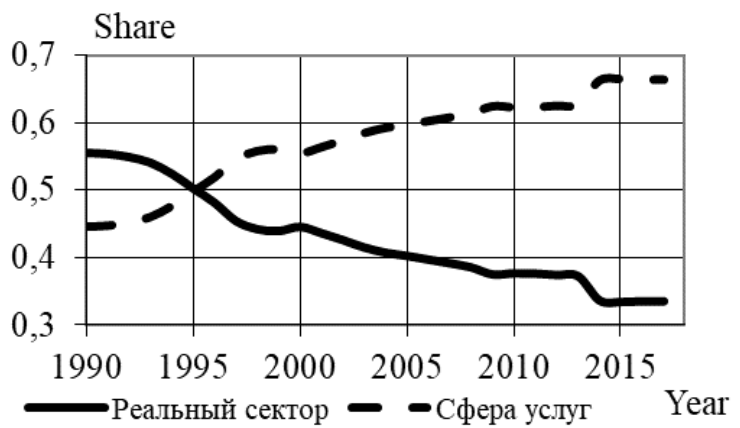

Figure 1. Change in employment ratio in manufacturing and non-manufacturing sectors in Russia [13]

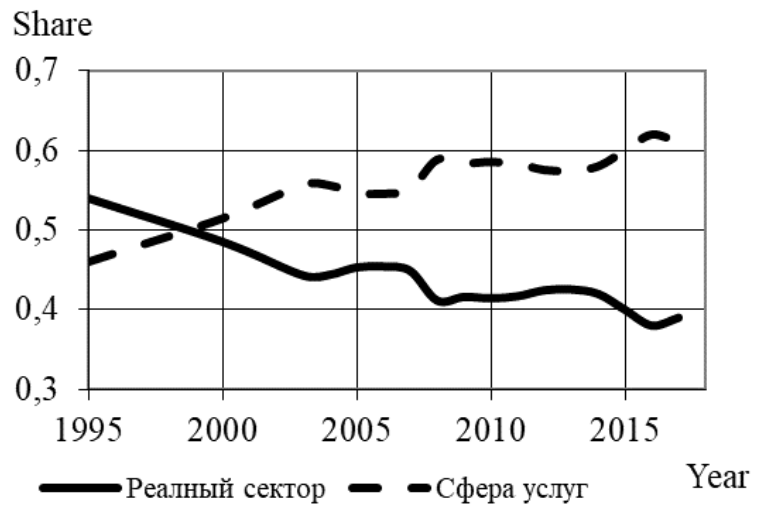

Figure 2. Change in the ratio of employment in manufacturing and non-manufacturing sectors in the Volgograd region [13]

Due to the formation of such a "cross" it can be recommended not only to preserve the change in the shares of employment in the real sector of the economy and in the service sector against the background of each other, but to offer a tool that allows one to combine two structural elements into one.

Let us denote the proposed tool through the coefficient of the structure of employment (the ratio of employed in "B" to those employed in "A" showing the final ratio of employed in the manufacturing and nonmanufacturing sectors.

According to official statistics, in 1990 across the country as a whole 41,794 thousand people worked in the manufacturing sector and 33,531 thousand people worked in the non-production sector with an employment structure ratio of 0.8 , then by the end of 2019, 25,071 thousand people worked in the manufacturing sector and in the non-productive sector there are 47593 thousand people with an employment structure coefficient of 1.9 [14].

To put it another way, today there are 2 jobs in the non-production sector per worker in the manufacturing sector whereas 27 years ago, the value of this coefficient on the contrary was 1.2 jobs in the manufacturing sector per one job in the service sector.
Employment data by industry for 1995-1996 show approximately equal shares, 0.99 and 1.07 , respectively, when one job in one consolidated group of types of economic activities of a production nature also had 1 job in the group of non-production sectors.

With a decrease in the total number of employed people in Russia by 2,661 thousand people (minus 3.5\%) over the analyzed period from 1990 to 2019, the values in absolute and relative terms for employment in the real sector of the economy and for employment in the service sector have fundamentally changed.

Thus, in the real sector of the economy there was a decrease in jobs from 41,794 thousand people to 25,071, the retirement amounted to 16,723 thousand people or $59.99 \%$, and in the service sector, the growth of employment was 14,062 thousand people or $41.94 \%$ increasing from 33531 thousand people in 1990 to 47 593 thousand people in 2019.

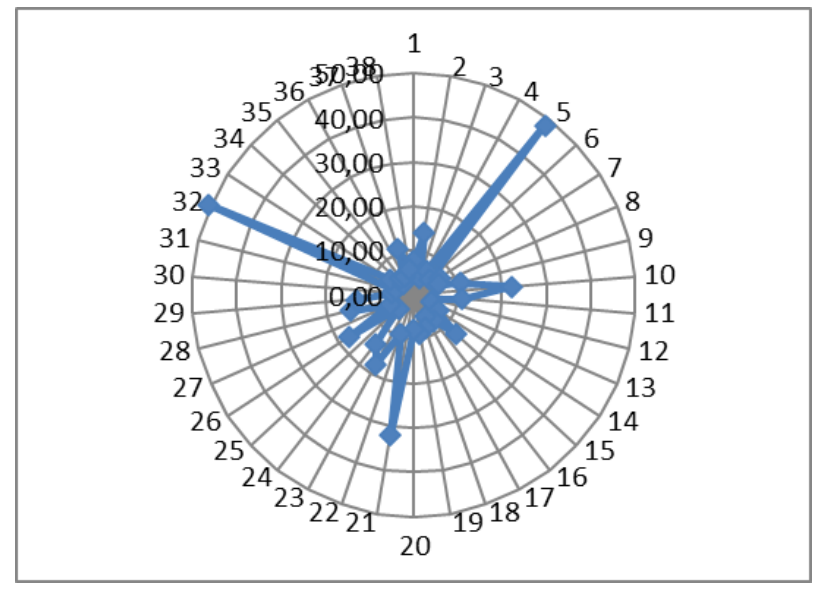

Figure 3. Employment structure ratio of municipalities of the Volgograd region [13]

The additional detailing of the structure of employment in the service sector is an important direction of this research as it highlights in a separate group "B" those employed in the spheres, 95 percent financed by the government is education; activities in the field of health and social services; public administration and military security and social security. In such conditions, the layout of the employment structure coefficient for the Volgograd region indicates that there are 4 jobs in the service sector per worker in the real sector of the economy, 2 of which are financed by the state.

As a result of the development of the structure of employment coefficient as well as its detailing and the allocation of a separate segment, an effective lever for managing the employment of the population appears both in the municipality, region, and country as a whole. The proposed tool is applicable to any territory which is its versatility.

This multiplier effect makes it possible to identify in which particular area of economic activity it is worth attracting investments in order to maintain employment in the main industry and related industries [15].

\section{Conclusion}


When making a management decision using the coefficient of the employment structure of the population and the calculated indicators of the cost of creating one job in each separate type of economic activity, it is possible to carry out using simple mathematical calculations - how much investment is required to create (maintain) jobs in "A" in order to automatically jobs were created in "B" with government funding of jobs in "C".

In the context of economy modernization, it is important to follow rapid changes both in general and in particular, therefore an important tool in the modern labor market is the identification of relevant tools, such as monitoring the structure of employment of the population by industry through the indicator of the coefficient of the structure of employment of the population which makes it possible to offer effective directions labor market management of the relevant territory.

\section{References}

1. H. Wang, L. Ding, R. Guan, Y. Xia, Technological Forecasting and Social Change, 161 (2020) https://doi.org/10.1016/j.techfore.2020

2. M.A. Ortskhanova, M.I. Kitieva, F.Ya. Polonkoeva, Competitiveness in the Global World: Economics, Science, Technology 4-4 (40), 111-117 (2017)

3. V.S. Dubrovina, E.A. Chumakova, Collection of materials of the 18 annual open competition of research works of students and young scientists in the field of economics and management "Green Sprout", 5-6 (2018)

4. O.A. Kolennikova, M.S. Toksanbaeva, Population 3 (77), 90-104 (2017)

5. E. Cruz, X. Raurich, Review of Economic Dynamics $\quad 38, \quad 198-219 \quad$ (2020) https://doi.org/10.1016/j.red.2020.04.004

6. M. Metin Başbay, C. Elgin, O. Torul, Economic $\begin{array}{llll}\text { Systems } & \text { 42, (2018) 556-568 }\end{array}$ https://doi.org/10.1016/j.ecosys.2018.03.003

7. T. Tsekeris, Cities, $95 \quad$ (2019) https://doi.org/10.1016/j.cities.2019.102472.

8. J. Clemens, M. Wither, Journal of Public Economics 170, 53-67 (2019)

9. G. Van den Broeck, T. Kilic, World Development 119, 81-99 (2019) https://doi.org/10.1016/j.worlddev.2019.03.008

10. V.N Arkhangelsky, Yu.V. Zinkina, S.G. Shulgin, Population 21-2, 18-34 (2018)

11. I. Haaland, C. Roth, Journal of Public Economics 191 (2020) https: //doi.org/10.1016/j.jpubeco.2020.104256

12. G. Gozgor, Structural Change and Economic Dynamics 45, 77-83 (2018)
13. Official site of the Federal State Statistics Service, URL: http://www.gks.ru (date of access: $01.12 .2020)$

14. A.V. Molostova, E.A. Chumakova, Materials of the national scientific-practical conference dedicated to the memory of Professor Z.N. Boschaeva, 19-20 (2019)

15. O.A. Aleksandrova, Yu.S. Nenakhova, A.V. Yarasheva, Population 1 (75), 34-46 (2017) 